\title{
Identification of Brevibacterium from clinical sources
}

\author{
DG PITCHER, H MALNICK \\ From the National Collection of Type Cultures, Central Public Health Laboratories, London NW9 5HT
}

SUMMARY Coryneform bacteria of the genus Brevibacterium occur on the normal skin surface, but reports of human infection with this genus are lacking. A number of cultures of coryneform bacteria sent to the National Collection of Type Cultures for identification have been identified as Brevibacterium spp on the basis of their cell wall composition and ability to produce methanethiol from L-methionine. We describe a rapid method for the detection of methane-thiol and confirmatory tests which differentiate Brevibacterium from morphologically similar genera.

Of 27 isolates of coryneform bacteria which were sent to the National Collection of Type Cultures for identification but which could not be identified by conventional tests, 13 conformed to the genus Brevibacterium in the rapid production of methanethiol from L-methionine and possessing the cell wall component meso-diaminopimelic acid but not arabinose. Two strains were of animal origin. One was a tissue culture contaminant and eight were from a variety of sites in the human body. These were compared with 11 reference cultures of Brevibacterium spp, eight Brevibacterium strains isolated from human skin,' 41 reference Corynebacterium spp, and seven other Gram positive bacteria. The results show that on the basis of four tests, Brevibacterium isolates can be clearly differentiated from Corynebacterium spp, which may be encountered in clinical specimens.

\section{Material and methods}

Cultures were maintained in the freeze dried state and plated on to nutrient agar (Oxoid) as required. Bacterial strains and their sources are listed in Table 1.

\section{BIOCHEMICAL TESTS}

Test media were inoculated by transferring a loopful of cells from a $24 \mathrm{~h}$ growth on nutrient agar. All tests were carried out at $30^{\circ} \mathrm{C}$ and $37^{\circ} \mathrm{C}$ and were examined at $24 \mathrm{~h}, 7$ days, and 14 days. Milk casein hydrolysis was tested on litmus milk agar. ${ }^{2}$ Degradation of tyrosine and xanthine was tested on nutrient agar containing well dispersed suspensions of $4 \%$

Accepted for publication 30 August 1984 (wt/vol) L-tyrosine and xanthine respectively. Positive results were indicated by the presence of zones of clearing around areas of growth.

\section{DETECTION OF METHANE-THIOL PRODUCTION Milk-DTNB medium}

A modification of the method of Laakso ${ }^{3}$ was used to detect methane-thiol production on a solid medium. Low fat skimmed milk (Oxoid), $30 \mathrm{~g}$, was dispersed in distilled water to $500 \mathrm{ml}$ and heated to $100^{\circ} \mathrm{C}$ with constant mixing. A separate solution $(500 \mathrm{ml})$ contained agar $10 \mathrm{~g}$, L-methionine $1 \mathrm{~g}$, $\mathrm{K}_{2} \mathrm{HPO}_{4} \mathrm{lg}$, and 55 , dithiobis-2-nitrobenzoic acid (DTNB) $0 \cdot 2 \mathrm{~g}$ (Sigma).

Both solutions were sterilised by autoclaving at 15 psi for $10 \mathrm{~min}$, after which the temperature was lowered to $50^{\circ} \mathrm{C}$. The solutions were mixed and distributed as $2 \mathrm{ml}$ slopes in bijoux bottles. Duplicate slopes were heavily inoculated with a loopful of culture from a nutrient agar plate; the bottles were tightly capped and incubated at $30^{\circ} \mathrm{C}$ and $37^{\circ} \mathrm{C}$. The slopes were inspected at $4 \mathrm{~h}$ and $20 \mathrm{~h}$. The presence of a bright yellow colour due to the formation of an aryl mercaptan diffusing through the medium was accepted as a positive result.

DETECTION OF CELL WALL COMPONENTS Samples for cell wall analysis were prepared as described by Bousfield et al. ${ }^{4}$ meso-diaminopimelic acid and neutral sugars were identified in hydrolysates by thin layer chromatography as described by Pitcher. ${ }^{5}$

\section{Results}

Table 2 lists the results of biochemical tests on Bre- 
Table 1 Sources of strains

\begin{tabular}{|c|c|c|c|c|}
\hline Original designation & NCTC number & Source & Isolated from & Reference \\
\hline $\begin{array}{l}\text { L1 } \\
\text { L29 } \\
\text { L55 } \\
\text { L65 } \\
\text { P151 } \\
\text { D69 } \\
\text { K656 } \\
\text { K673 } \\
- \\
- \\
- \\
- \\
- \\
-\end{array}$ & $\begin{array}{l}\text { A288/80 } \\
\text { A290/80 } \\
\text { A289/80 } \\
\text { A291/90 } \\
\text { A293/80 } \\
\text { A286/80 } \\
\text { A100/80 } \\
\text { A287/80 } \\
\text { A } 37 / 73 \\
\text { A } 76 / 79 \\
\text { A76/84 } \\
\text { A232/83 } \\
\text { A12/79 } \\
\text { A40/71 } \\
\text { A } 127 / 80 \\
\text { A119/74 } \\
\text { A } 128 / 84 \\
\text { A220/80 } \\
\text { A2/73 }\end{array}$ & $\begin{array}{l}\text { D Pitcher, London } \\
\text { D Pitcher, London } \\
\text { D Pitcher, London } \\
\text { D Pitcher, London } \\
\text { D Pitcher, London } \\
\text { R van Furth, Netherlands } \\
\text { JJ Leyden, USA } \\
\text { JJ Leyden, USA } \\
\text { JA Vale and GW Scott, London } \\
\text { R Terry, Burnley } \\
\text { MR Miller, Leeds } \\
\text { J Kensit, London } \\
\text { RJC Hart, Exeter } \\
\text { JA Vale and GW Scott, London } \\
\text { DI Annear, Australia } \\
\text { Tanzania } \\
\text { PL Hood, Brunel University } \\
\text { K Mohan, Nigeria } \\
\text { SD Elek, London }\end{array}$ & $\begin{array}{l}\text { Normal human skin } \\
\text { Normal human skin } \\
\text { Normal human skin } \\
\text { Normal human skin } \\
\text { Normal human skin } \\
\text { Normal human skin } \\
\text { Toe clefts-tinea pedis } \\
\text { Toe clefts-tinea pedis } \\
\text { Ear-bilateral ororrhea } \\
\text { Ear (same strain, several patients) } \\
\text { Blood culture } \\
\text { Blood culture (possible contaminant) } \\
\text { Blood culture } \\
\text { Cerebrospinal fluid } \\
\text { Hip sinus } \\
\text { Discharging sinus of foot } \\
\text { Mouse-liver } \\
\text { Poultry-bumblefoot disease } \\
\text { lissue culture }\end{array}$ & $\begin{array}{l}11 \\
11 \\
11 \\
11 \\
10\end{array}$ \\
\hline
\end{tabular}

vibacterium spp and reference bacteria. $B$ linens and $B$ iodinum grew on all media at $30^{\circ} \mathrm{C}$ but not at $37^{\circ} \mathrm{C}$ and results at $30^{\circ} \mathrm{C}$ only are recorded. For other reference bacteria and Brevibacterium strains the results at $30^{\circ} \mathrm{C}$ and $37^{\circ} \mathrm{C}$ did not differ.

GROWTH AND REACTION ON MILK-DTNB AGAR With the exception of Corynebacterium renale and Mycobacterium smegmatis, species of Corynebacterium and Gram positive reference bacteria grew poorly or not at all on milk-DTNB agar.

All strains of Brevibacterium produced a pronounced yellowing of the milk-DTNB in $4 \mathrm{~h}$, which was not observed in other species, although Mycobacterium smegmatis developed this colour in $20 \mathrm{~h}$.

\section{CONFIRMATORY BIOCHEMICAL TESTS}

Caseinolysis could not be observed on milk-DTNB agar except in a small number of strains after prolonged incubation and was probably due to the thickness of the slopes. On litmus-milk-agar plates, however, zones of clearing were apparent at seven days in all Brevibacterium except two strains of $B$ linens and one of the human isolates (A76/84). Among the reference strains, only $C$ renale exhibited caseinolysis.

Tyrosine was degraded by all Brevibacterium strains, by $C$ minutissimum (four strains), by one strain of $C$ xerosis and three of 20 clinical isolates of Corynebacterium. Xanthine was degraded by all culture collection strains of Brevibacterium. Results for skin and test Brevibacterium strains varied, however; 11 of 19 strains were positive. All other coryneform and reference cultures failed to degrade xanthine.

Results for casein, tyrosine, and xanthine hydrolysis were recorded after seven days' incubation.
Further incubation to 14 days did not show any late activity.

\section{CELL WALLS}

All strains designated Brevibacterium possessed meso-diaminopimelic acid and galactose but not arabinose in their cell walls. All strains described as Corynebacterium spp contained meso-diaminopimelic acid and arabinose.

\section{Discussion}

The genus Brevibacterium was previously considered incertae sedis ${ }^{6}$ but has now been amended to describe species with chemotaxonomic characters closely resembling $B$ linens. ${ }^{7}$ Four species have been described which comply with the generic criteria: $B$ linens (amended description) and $B$ iodinum, ${ }^{7} B$ casei, and $B$ epidermidis. ${ }^{8} B$ linens and $B$ iodinum grow poorly or not at all at $37^{\circ} \mathrm{C}$. The former species exhibits a yellow to orange pigment particularly in the light, and the latter produces blue extracellular crystals of iodinum under suitable conditions. All four species of Brevibacterium are respiratory aerobes and do not ferment sugars. This, together with their coryneform morphology, may in the past have led to their misidentification as $C$ bovis. ${ }^{9}$ Two strains, A37/73 and A40/71, were so described by Vale and Scott. ${ }^{10} \mathrm{C}$ bovis, however, is not proteolytic and does not produce methane-thiol from methionine.

Sharpe et al" studied the properties of methanethiol producing coryneform bacteria from cheese, milk, and human skin and found them to possess the Brevibacterium cell wall type. Although Brevibacterium spp have been reported as occurring on the human skin surface' and may produce antibiotics which affect the distribution of the normal flora, ${ }^{12}$ 
Table 2 Cell wall type and biochemical results

\begin{tabular}{|c|c|c|c|c|c|c|c|c|}
\hline \multirow[t]{3}{*}{ Reference strains } & \multirow[t]{3}{*}{ Source } & \multicolumn{2}{|c|}{ Cell wall } & \multirow{2}{*}{\multicolumn{2}{|c|}{$\begin{array}{l}\text { Production of } \\
\text { methane-thiol }\end{array}$}} & \multirow{3}{*}{$\begin{array}{l}\text { Tyrosine } \\
\text { degraded }\end{array}$} & \multirow{3}{*}{$\begin{array}{l}\text { Xanthine } \\
\text { degraded }\end{array}$} & \multirow{3}{*}{$\begin{array}{l}\text { Casein } \\
\text { hydrolysed }\end{array}$} \\
\hline & & \multirow{2}{*}{$m D A P$} & \multirow{2}{*}{$\overline{\text { Arabinose }}$} & & & & & \\
\hline & & & & $4 h$ & $20 h$ & & & \\
\hline & & \multicolumn{7}{|c|}{ Corynebacterium spp } \\
\hline$C$ bovis & NCTC 3224 & + & + & - & - & - & - & - \\
\hline C diphtheriae & NCTC 3984 & + & + & - & - & - & - & _- \\
\hline C kitscheri & NCTC 949 & + & + & - & - & - & - & - \\
\hline C minutissimum & NCTC 10284 & + & + & - & - & + & - & - \\
\hline C minutissimum & NCTC 10285 & + & + & - & - & + & _- & _- \\
\hline C minutissimum & NCTC 10288 & + & + & - & - & + & - & _- \\
\hline C minutissimum & NCTC 10289 & + & + & _- & - & + & _- & _ \\
\hline C mycetoides & NCTC 9864 & + & + & _- & - & - & _- & _- \\
\hline C pilosum & ATCC 29592 & + & + & - & - & - & - & - \\
\hline C pseudodiphtheriticum & NCTC 231 & + & + & - & - & - & - & - \\
\hline C pseudodiphtheriticum & NCTC 8633 & + & + & - & - & - & - & - \\
\hline C pseudodiphtheriticum & NCTC 8634 & + & + & - & - & - & - & - \\
\hline C renale & NCTC 7448 & + & + & - & - & - & - & + \\
\hline C striatum & NCTC 764 & + & + & - & - & - & - & - \\
\hline C ulcerans & NCTC 7910 & + & + & - & - & - & - & - \\
\hline C xerosis & ATCC 373 & + & + & - & - & - & - & - \\
\hline Cxerosis & ATCC 7094 & + & + & - & - & + & _- & _- \\
\hline Cxerosis & NCTC 7243 & + & + & - & - & - & _- & _- \\
\hline Cxerosis & NCTC 7883 & + & + & - & - & - & - & - \\
\hline Cxerosis & NCTC 7929 & + & + & _- & _- & _- & _- & _- \\
\hline Cxerosis & NCTC 9755 & + & + & _- & - & _- & _- & _- \\
\hline \multirow{2}{*}{$\begin{array}{l}\text { Corynebacterium spp } \\
\text { (clinical isolates) }\end{array}$} & 20 strains & $20 / 20$ & $20 / 20$ & $0 / 20$ & $0 / 20$ & $3 / 20$ & $0 / 20$ & $0 / 20$ \\
\hline & & \multicolumn{7}{|c|}{ Other Gram positive bacteria } \\
\hline Actinomyces pyogenes & NCTC 5224 & - & - & - & - & - & - & - \\
\hline Caseobacter polymorpha & ATCC 33010 & + & + & - & - & - & - & - \\
\hline Erysipelothrix rhusiopathiae & NCTC 8163 & - & - & - & - & _- & - & _- \\
\hline Listeria monocytogenes & NCTC 7973 & + & - & - & _- & _- & _- & _- \\
\hline Micrococcus luteus & NCTC 2665 & - & - & _- & _- & _- & _- & _- \\
\hline Mycobacterium smegmatis & NCTC 8159 & + & + & - & + & _- & _ & _ \\
\hline Rhodococcus equi & NCTC 1621 & + & + & - & - & - & - & - \\
\hline & & & & & evibac & $n$ spp & & \\
\hline$B$ linens & NCIB 8546 & + & - & + & + & + & + & + \\
\hline$B$ linens & NCIB 8377 & + & - & + & + & + & + & - \\
\hline$B$ linens & ATCC 19391 & + & - & + & + & + & + & + \\
\hline$B$ linens & ATCC 9172 & + & - & + & + & + & + & - \\
\hline$B$ linens & NCDO 1002 & + & - & + & + & + & + & + \\
\hline$B$ casei & NCDO 2051 & + & - & + & + & + & + & + \\
\hline$B$ casei & NCDO 2048 & + & - & + & + & + & + & + \\
\hline$B$ iodinum & NCDO 613 & + & - & + & + & + & + & + \\
\hline$B$ iodinum & NCTC 9742 & + & - & + & + & + & + & + \\
\hline$B$ epidermidis & NCTC 11083 & + & - & + & + & + & + & + \\
\hline$B$ epidermidis & NCTC 11084 & + & - & + & + & + & + & + \\
\hline & & & & & ates (s & ble 1) & & \\
\hline & A288/80 & + & - & + & + & + & + & $T$ \\
\hline & A290/80 & + & - & + & + & + & + & + \\
\hline & A289/80 & + & - & + & + & + & - & + \\
\hline & A291/80 & + & - & + & + & + & - & + \\
\hline & A293/80 & + & - & + & + & + & + & + \\
\hline & A286/80 & + & - & + & + & + & + & + \\
\hline & $\mathrm{A} 100 / 80$ & + & - & + & + & + & - & + \\
\hline & A $287 / 80$ & + & - & + & + & + & + & + \\
\hline & A $37 / 73$ & + & - & + & + & + & - & + \\
\hline & A 76/79 & + & - & + & + & + & - & + \\
\hline & A $76 / 84$ & + & - & + & + & + & + & - \\
\hline & A $232 / 83$ & + & - & + & + & + & + & + \\
\hline & A 1279 & + & - & + & + & + & + & + \\
\hline & A $40 / 71$ & + & - & + & + & + & - & + \\
\hline & A $127 / 80$ & + & - & + & + & + & - & + \\
\hline & A $119 / 74$ & + & - & + & + & + & + & + \\
\hline & A $128 / 84$ & + & - & + & + & + & + & + \\
\hline & $\mathrm{A} 220 / 80$ & + & - & + & + & + & - & + \\
\hline & A $2 / 73$ & + & - & + & + & + & + & + \\
\hline
\end{tabular}

$B$ linens and $B$ iodinum - poor or no growth at $37^{\circ} \mathrm{C}$; results are for $30^{\circ} \mathrm{C}$. All other results are for $30^{\circ} \mathrm{C}$ and $37^{\circ} \mathrm{C}$. mDAP = meso-diaminopimelic acid. 
reports of human or animal infection with Brevibacterium isolates are lacking, with the exception of one description of bumblefoot disease in poultry from which coryneform bacteria closely resembling Brevibacterium were isolated. ${ }^{13}$ One of these (A220/80) is included in our study.

$B$ linens produces a variety of volatile sulphur products, including compounds which are important in the flavour and aroma of cheeses, while enrichment of the growth medium with L-methionine increases the concentration of methane-thiol produced. ${ }^{14}$

All the Brevibacterium strains included in this study had a potent cheese like smell on incubation and gave a positive milk-DTNB test. Thus it is likely that the production of volatile sulphur compounds is a shared characteristic of other species in the genus. Volatile sulphides including methane-thiol are produced by Gram negative bacteria of several genera associated with stored fish and poultry spoilage. These have been detected by the yellowing of filter papers impregnated with DTNB suspended above cultures of food spoilage bacteria grown in medium supplemented with cysteine and methionine, to detect both hydrogen sulphide and volatile organic sulphides. ${ }^{15}$ Utilising the ability of Brevibacterium to grow on milk agar, a medium on which Corynebacterium species grow poorly, and incorporating DTNB and L-methionine enable these two genera to be clearly separated. The confirmation tests of casein, tyrosine, and xanthine hydrolysis serve to enhance the distinction.

Brevibacterium isolates in clinical material may be contaminants derived from human skin or from the environment or they may be secondary invaders. The possibility remains, however, that because the genus has not been considered as a source of potential pathogens, isolates have in the past been misidentified as Corynebacterium species. None of the clinical isolates of Brevibacterium that we have studied produced the characteristic pigments of $B$ linens and $B$ iodinum and all grew well at $37^{\circ} \mathrm{C}$. At present, however, a distinction between $B$ casei and $B$ epidermidis cannot be made on the basis of morphology, colonial appearance, or biochemical tests. The essential difference is one of habitat: $B$ case $i$ isolates are from dairy products and $B$ epidermidis are from human skin. In the absence of adequate species differentiation we can only describe the clinical isolates as Brevibacterium sp.

We are grateful to Dr LR Hill for his advice.

\section{References}

' Pitcher DG. Rapid identification of cell wall components as a guide to the classification of aerobic coryneform bacteria from human skin. J Med Microbiol 1977; 10:439-46.

2 Webster GF. McGinley KJ. Use of litmus milk agar for presumptive identification of cutaneous propionibacteria. J Clin Microbiol 1977:5:661-2.

'Laakso S. The relationship between methionine uptake and demethiolation in a methionine utilizing mutant of Pseudomonas fuorescens UK I. J Gen Microbiol 1976:95:391-4.

4 Bousfield IJ. Smith GL. Dando TR. Hobbs G. Numerical analysis of total fatty acid profiles in the identification of coryneform. nocardioform and some other bacteria. J Gen Microbiol 1983; 129:375-94.

'Pitcher DG. Deoxyribonucleic acid base- composition of Corynebacterium diphtheriae and other corynebacteria with cell wall type IV. FEMS Microbiol Lett 1983;16:291-5.

- Buchanan RE. Gibbons NE. eds. Bergey's manual of determinative bacteriology, 8th ed. Baltimore: Williams and Wilkins. 1974.

- Collins MD. Jones D. Keddie RM. Sneath PHA. Reclassification of Chromobacterium iodinum (Davis) in a redefined genus Brevibacterium (Breed) as Brevibacterium iodinum nom. rev.: comb. nov. J Gen Microbiol 1980;120: 1-10.

${ }^{8}$ Collins MD. Farrow JAE. Goodfellow M, Minnikin DE. Brevibacterium casei $\mathrm{sp}$ nov and Brevibacterium epidermidis $\mathrm{sp}$ nov. System Appl Microbiol 1983:4:388-95.

"Hine JE, Hill LR, Lapage SP. Corynebacterium spp in human disease. Lancet 1978;ii: 376.

${ }^{10}$ Vale JA, Scott GW. Corynebacterium bovis as a cause of human disease. Lancet 1977; ii: 682.

"Sharpe ME, Law BA, Phillips BA, Pitcher DG. Methane-thiol production by coryneform bacteria: strains from dairy and human skin sources and Brevibacterium linens. J Gen Microbiol 1977; 101:345-9.

$\therefore$ Al-Admawy AM, Noble WC. Antibiotic production by cutaneous Brevibacterium sp. J Appl Bacteriol 1981;51:535-40.

${ }^{13}$ Mohan K. Brevibacterium sp from poultry. Antonie van Leeuwenhoek 1981;47:449-53.

${ }^{14}$ Cuer A, Dauphin G, Kergomard A, Dumont JP, Adda J. Production of S-methylthioacetate by Brevibacterium linens. Appl Environ Microbiol 1979;38:332-4.

is McMeekin TA, Gibbs PA, Patterson JT. Detection of volatile sulphide-producing bacteria isolated from poultry processing plants. Appl Environ Microbiol 1978;35:1216-8.

Requests for reprints to: Dr DG Pitcher, National Collection of Type Cultures, Central Public Health Laboratory, Colindale Avenue, London NW9 5HT, England. 